\title{
Muricauda lutaonensis sp. nov., a moderate thermophile isolated from a coastal hot spring
}

\author{
Correspondence \\ Chiu-Chung Young \\ ccyoung@mail.nchu.edu.tw
}

\author{
A. B. Arun, ${ }^{1}$ Wen-Ming Chen, ${ }^{2}$ Wei-An Lai, ${ }^{1}$ Jiu-Hsing Chao, ${ }^{1}$ \\ P. D. Rekha, ${ }^{1}$ Fo-Ting Shen, ${ }^{1}$ Satnam Singh ${ }^{1}$ and Chiu-Chung Young ${ }^{1}$
}

\author{
${ }^{1}$ College of Agriculture and Natural Resources, Department of Soil \& Environmental Sciences, \\ National Chung Hsing University, Taichung 402, Taiwan, ROC \\ ${ }^{2}$ Laboratory of Microbiology, Department of Seafood Science, National Kaohsiung Marine \\ University, Kaohsiung City 811, Taiwan, ROC
}

\begin{abstract}
A yellow-pigmented, Gram-staining-negative, aerobic, non-motile, moderately thermophilic, rodshaped bacterium, designated strain CC-HSB $-11^{\top}$, was isolated from a coastal hot spring of Green Island (Lutao), located off Taituang, Taiwan. 16S rRNA gene sequence analysis demonstrated that it shared $<94.4 \%$ sequence similarity with Muricauda species. Menaquinone with six isoprene units (MK-6) was the major respiratory quinone and iso- $\mathrm{C}_{15: 0}$, iso- $\mathrm{C}_{15: 1} \mathrm{G}$, iso$\mathrm{C}_{15: 0} 3-\mathrm{OH}$, iso- $\mathrm{C}_{16: 0} 3-\mathrm{OH}$, iso- $\mathrm{C}_{17: 0} 3-\mathrm{OH}$ and summed feature 3 (comprising iso- $\mathrm{C}_{15: 0}$ 2- $\mathrm{OH}$ and/or $\mathrm{C}_{16: 1} \omega 7 \mathrm{c} / \mathrm{t}$ ) were the predominant fatty acids. The predominant polar lipids were diphosphatidylglycerol, phosphatidylglycerol and phosphatidylethanolamine. Six unidentified phospholipids and glycolipids also occurred as minor components. The DNA G+C content of strain CC-HSB-11 ${ }^{\top}$ was $46.4 \pm 1$ mol\%. On the basis of $16 \mathrm{~S}$ rRNA gene sequence similarities with other Muricauda species and differentiating fatty acid compositions and other phenotypic data, strain CC-HSB-11 ${ }^{\top}$ represents a novel species in the genus Muricauda, for which the name Muricauda lutaonensis sp. nov. is proposed. The type strain is CC-HSB-11 ${ }^{\top}\left(=\mathrm{BCRC} 17850^{\top}\right.$ $=$ KCTC $22339^{\top}$ ).
\end{abstract}

During investigations of the biodiversity of marine bacteria from water samples collected at a coastal hot spring (water temperature $55^{\circ} \mathrm{C}$ ) located on a volcanic island [Lutao (Green Island), $\left.22^{\circ} 40^{\prime} \mathrm{N} 121^{\circ} 27^{\prime} \mathrm{E}\right]$ in the Pacific Ocean, off the east coast of Taiwan, strain CC-HSB- $11^{\mathrm{T}}$ was isolated on marine agar 2216 (MA; Difco) after incubation at $37{ }^{\circ} \mathrm{C}$ for $48 \mathrm{~h}$. Subcultivation was done on MA at $37{ }^{\circ} \mathrm{C}$ for 2 days. The strain was preserved at $-80{ }^{\circ} \mathrm{C}$ in marine broth 2216 (MB; Difco) with $20 \%$ (v/v) glycerol or by lyophilization.

The $16 \mathrm{~S}$ rRNA gene sequence of strain CC-HSB- $11^{\mathrm{T}}$ was determined and analysed as described previously (Young et al., 2005). Analysis was performed by using the software package MEGA version 2.1 (Kumar et al., 2001), after multiple data alignments with CLUSTAL X (Thompson et al., 1997). A distance-matrix method (distance options according to Kimura's two-parameter model), including clustering by neighbour joining (Saitou \& Nei, 1987) (Fig. 1), and a discrete character-based maximum-parsimony method (Kluge \& Farris, 1969) were used. In each

The GenBank/EMBL/DDBJ accession number for the 16S rRNA gene sequence of strain CC-HSB- $11^{\top}$ is EU564844.

The polar lipid profile of strain CC-HSB- $11^{\top}$ is available as supplementary material with the online version of this paper. case, bootstrap values were calculated based on 1000 replications. The $16 \mathrm{~S}$ rRNA gene sequence of strain CCHSB $-11^{\mathrm{T}}$ was a continuous stretch of $1438 \mathrm{bp}$. Sequence similarity calculations indicated that strain CC-HSB- $11^{\mathrm{T}}$ showed the greatest degree of similarity to Muricauda aquimarina $\mathrm{SW}-63^{\mathrm{T}}(94.4 \%), M$. lutimaris $\mathrm{SMK}-108^{\mathrm{T}}$ (94.3\%), M. ruestringensis $\mathrm{B}^{\mathrm{T}}(94.1 \%)$ and M. flavescens SW-62 $2^{\mathrm{T}}(93.1 \%)$. Lower sequence similarities $(<92 \%)$ were found with all other representatives of the family Flavobacteriaceae shown in Fig. 1. Strain CC-HSB-11 ${ }^{\mathrm{T}}$ formed a distinct branch supported by a high bootstrap percentage in the neighbour-joining (Fig. 1) and maximum-parsimony (data not shown) trees. DNA-DNA relatedness experiments were not carried out between strain CC-HSB $-11^{\mathrm{T}}$ and its closest phylogenetic neighbours in the genus Muricauda, as the 16S rRNA gene sequence similarities between strains were less then $95 \%$ (Stackebrandt \& Goebel, 1994).

Gram staining was performed as described by Gerhardt et al. (1994) and poly- $\beta$-hydroxybutyrate granules were sought by staining the cells with Sudan black. Cell morphology was observed by light microscopy $(\times 1000$, model A3000; Zeiss) and transmission electron microscopy (1200 EX; JEOL) using cells grown for 3 days at $37{ }^{\circ} \mathrm{C}$ on MA. The latter technique was also used to search for 


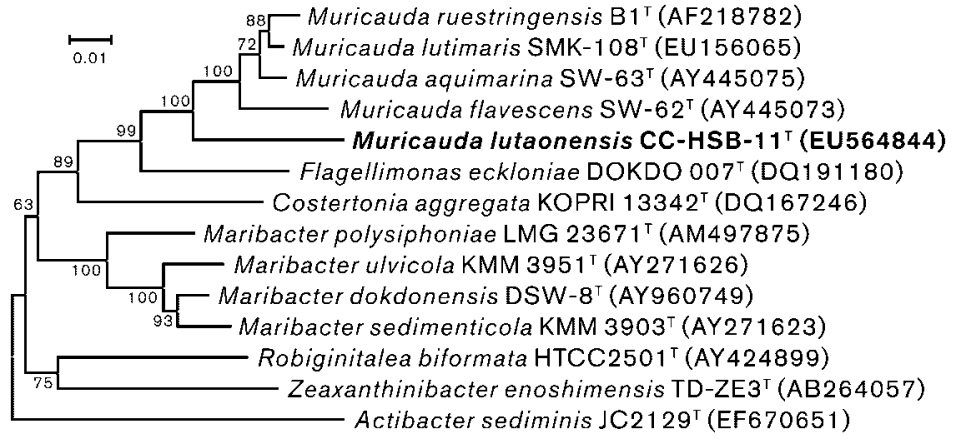

Fig. 1. Neighbour-joining phylogenetic tree based on 16S rRNA gene sequences showing the relationship of strain CC-HSB- $11^{\top}$ and representatives of the family Flavobacteriaceae. Bootstrap values based on 1000 replications are shown at branch nodes. The sequence of Actibacter sediminis $\mathrm{JC} 2129^{\top}$ was used as the outgroup. Bar, 0.01 substitutions per nucleotide position. flagella or the kind of appendages reported for members of the genus Muricauda (Bruns et al., 2001; Yoon et al., 2005, 2008). Cells from exponentially growing cultures were negatively stained with $2 \%(\mathrm{w} / \mathrm{v})$ uranyl acetate and the grids were examined after being air dried. Gliding motility was investigated by using phase-contrast microscopy of a hanging-drop preparation from an MB culture (Bernardet et al., 2002).

The $\mathrm{pH}$ range for growth was determined in $\mathrm{MB}$ that was adjusted prior to sterilization to $\mathrm{pH} 3-11$ (in $0.5 \mathrm{pH}$ unit intervals) using appropriate biological buffers (Chung et al., 1995). Verification of the $\mathrm{pH}$ after autoclaving revealed only minor changes. Growth in $\mathrm{MB}$ at 10, 15, 20, 25, 30 and $35{ }^{\circ} \mathrm{C}$ and at $35-60{ }^{\circ} \mathrm{C}$ in $2{ }^{\circ} \mathrm{C}$ intervals was measured after 3 days of incubation. Anaerobic growth was assessed in $\mathrm{MB}$ and on MA supplemented with potassium nitrate ( $5 \mathrm{mM}$ ) incubated in an Oxoid AnaeroGen system (Miller et al., 1995). Growth with $1-10 \%(\mathrm{w} / \mathrm{v}) \mathrm{NaCl}$ in $1 \%$ increments was investigated in $\mathrm{MB}$. The requirement of strain CC-HSB- $11^{\mathrm{T}}$ for natural seawater and artificial sea salts was evaluated on R2A agar (Difco) and in tryptic soy broth (Difco) with and without the addition of $60 \%(\mathrm{v} / \mathrm{v})$ seawater or $0,1,2,3,4,5,7$ and $10 \%(\mathrm{w} / \mathrm{v})$ artificial sea salts (Sigma) (Lee, 2007). Growth with $\mathrm{NaCl}$ as the only salt was studied on R2A and trypticase soy agars supplemented with 0-9\% (w/v) NaCl. Growth under these different conditions was recorded by measuring the $\mathrm{OD}_{595}$ of the broth cultures with time.

The presence of flexirubin-type pigments was investigated as described by Reichenbach (1992) and Bernardet et al. (2002). Catalase and oxidase activities and hydrolysis of casein, starch and Tweens 20, 40, 60 and 80 were assessed as described by Cowan \& Steel (1965). Hydrolysis of aesculin, gelatin and urea and reduction of nitrate were investigated as described by Lányí (1987) with the modification that artificial seawater was used for the preparation of media. The artificial seawater contained (per litre distilled water) $23.6 \mathrm{~g} \mathrm{NaCl}, 0.64 \mathrm{~g} \mathrm{KCl}, 4.53 \mathrm{~g}$ $\mathrm{MgCl}_{2} \cdot 6 \mathrm{H}_{2} \mathrm{O}$, $5.94 \mathrm{~g} \quad \mathrm{MgSO}_{4} \cdot 7 \mathrm{H}_{2} \mathrm{O}$ and $1.3 \mathrm{~g}$ $\mathrm{CaCl}_{2} \cdot 2 \mathrm{H}_{2} \mathrm{O}$ (Bruns et al., 2001). $\mathrm{H}_{2} \mathrm{~S}$ production was tested as described by Bruns et al. (2001). Acid production from carbohydrates was determined as described by Leifson (1963). Other biochemical characteristics were investigated with the GN-II system (Biolog), API ZYM, API 20E, API 20NE and ATB PSE (bioMérieux) systems. Morphological features, especially the presence of appendages (Fig. 2) and other phenotypic characteristics of strain CC-HSB- $11^{\mathrm{T}}$, are listed in the genus and species descriptions and in Table 1.

Respiratory quinones of strain CC-HSB- $11^{\mathrm{T}}$ were extracted and separated as described by Minnikin et al. (1984) and analysed by HPLC as described by Collins \& Jones (1980). Menaquinone with six isoprene units (MK-6) was the predominant respiratory quinone $(>91 \%)$. The presence of MK-6 as the major respiratory quinone is in line with all members of the genus Muricauda.

Polar lipids were extracted and analysed by two-dimensional TLC according to Embley \& Wait (1994). The predominant polar lipids of strain CC-HSB- $11^{\mathrm{T}}$ were diphosphatidylglycerol, phosphatidylglycerol and phosphatidylethanolamine. Three unidentified phospholipids and three unidentified glycolipids were present in minor amounts (Supplementary Fig. S1, available in IJSEM online).

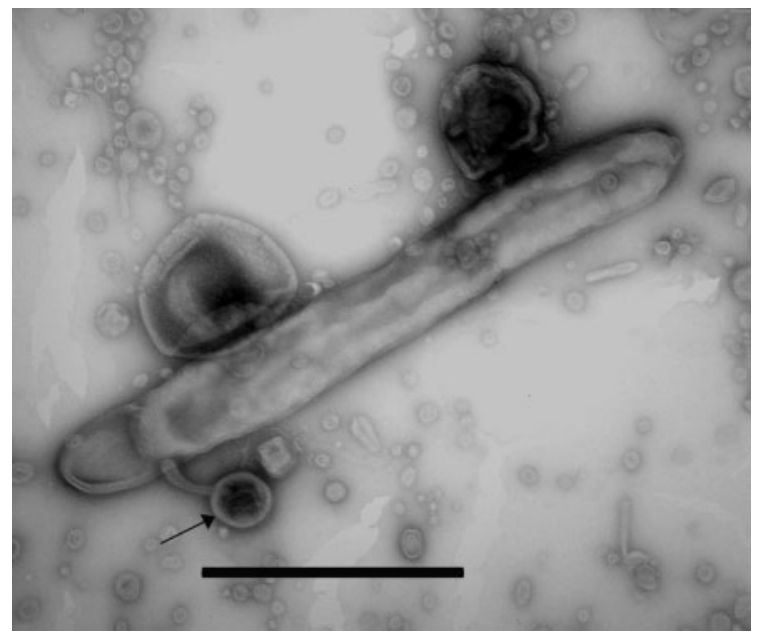

Fig. 2. Transmission electron micrograph showing appendages (arrow) found on a few cells of strain CC-HSB-11 ${ }^{\top}$. Bar, $1 \mu \mathrm{m}$. 
Table 1. Comparison of phenotypic characteristics of strain CC-HSB-11 ${ }^{\top}$ and type strains of recognized species in the genus Muricauda

Strains: 1, Muricauda lutaonensis sp. nov. CC-HSB-11 ${ }^{\mathrm{T}} ; 2$, M. lutimaris SMK-108 ${ }^{\mathrm{T}} ; 3$, M. ruestringensis DSM 13258 ${ }^{\mathrm{T}}$; 4 , M. flavescens SW-62 ${ }^{\mathrm{T}}$; 5 , M. aquimarina SW-63 ${ }^{\mathrm{T}}$. Data for reference type strains were taken from Yoon et al. (2008) (M. lutimaris SMK-108 ${ }^{\mathrm{T}}$ ) and Yoon et al. $(2005$ ) (remaining strains). All strains are Gram-staining-negative, non-spore-forming rods. All strains are positive for oxidase, alkaline phosphatase, esterase lipase (C8), leucine arylamidase, valine arylamidase, cystine arylamidase, $\alpha$-glucosidase and $N$-acetyl- $\beta$-glucosaminidase activities, hydrolysis of aesculin, tyrosine and Tween 20, utilization of D-fructose, cellobiose, sucrose and D-mannose and acid production from D-fructose, melibiose, D-mannose, cellobiose, lactose, sucrose, maltose, trehalose and raffinose. All strains are negative for growth without $\mathrm{NaCl}$ and at $4{ }^{\circ} \mathrm{C}$, nitrate reduction, $\mathrm{H}_{2} \mathrm{~S}$ production, presence of $\beta$-glucuronidase and $\alpha$-fucosidase activities, hydrolysis of starch and urea, utilization of citrate, lactate, formate, L-serine and mannitol and acid production from D-sorbitol, myo-inositol, D-ribose, D-mannitol and L-rhamnose. +, Positive; w, weakly positive; -, negative.

\begin{tabular}{|c|c|c|c|c|c|}
\hline Characteristic & 1 & 2 & 3 & 4 & 5 \\
\hline Catalase activity & + & + & $-{ }^{*}$ & + & + \\
\hline Facultative anaerobe & - & + & + & - & - \\
\hline \multicolumn{6}{|l|}{ Temperature for growth $\left({ }^{\circ} \mathrm{C}\right)$} \\
\hline Maximum & 55 & 39 & 40 & 44 & 44 \\
\hline Optimum & $37-45$ & 30 & $20-30$ & $30-37$ & $30-37$ \\
\hline \multicolumn{6}{|l|}{ Hydrolysis of: } \\
\hline Casein & + & + & - & - & - \\
\hline Gelatin & - & + & - & - & - \\
\hline Tweens 40, 60 and 80 & - & - & + & + & + \\
\hline \multicolumn{6}{|l|}{ Enzyme activity (API ZYM) } \\
\hline Esterase (C4) & + & + & - & + & + \\
\hline Lipase (C14) & + & - & - & - & - \\
\hline Trypsin & + & - & - & $\mathrm{w}$ & + \\
\hline$\alpha$-Chymotrypsin & - & + & - & + & + \\
\hline Acid phosphatase & + & + & + & - & + \\
\hline Naphthol-AS-BI-phosphohydrolase & + & + & + & - & + \\
\hline$\alpha$-Galactosidase & + & - & - & - & - \\
\hline$\beta$-Galactosidase & + & - & - & - & - \\
\hline$\beta$-Glucosidase & + & + & + & - & + \\
\hline$\alpha$-Mannosidase & + & - & - & - & - \\
\hline \multicolumn{6}{|l|}{ Utilization of (Biolog GN-II): } \\
\hline Glucose & + & + & - & + & + \\
\hline Lactose & + & - & + & + & + \\
\hline Raffinose & + & - & + & + & + \\
\hline Malate & - & - & + & - & - \\
\hline Succinate & + & - & + & + & + \\
\hline Alanine & - & - & + & - & - \\
\hline Arginine & - & - & + & - & - \\
\hline Acetate & + & - & - & - & - \\
\hline Glutamate & + & - & - & - & - \\
\hline \multicolumn{6}{|l|}{ Acid production from: } \\
\hline D-Glucose & - & + & + & + & + \\
\hline D-Xylose & - & - & + & - & - \\
\hline L-Arabinose & - & + & + & - & - \\
\hline Melezitose & + & + & + & + & - \\
\hline D-Galactose & - & + & + & - & - \\
\hline DNA G + C content $(\mathrm{mol} \%)$ & 46.4 & 41.1 & 41 & $45.2-45.4 \dagger$ & $44.1-44.2 \dagger$ \\
\hline
\end{tabular}

${ }^{\star}$ Reported as negative by Bruns et al. (2001) but positive by Yoon et al. (2005).

$\dagger$ Range of values for two strains, including the type strain.

Fatty acid methyl esters were obtained from cells cultivated on MA for 3 days at $30{ }^{\circ} \mathrm{C}$ by saponification, methylation and extraction as described by Kämpfer \& Kroppenstedt (1996) and separated by gas chromatography (model
5898A; Hewlett Packard). Peaks were automatically integrated and fatty acid names and percentages were determined using the Microbial Identification standard software package (Sasser, 1990). The detailed fatty acid 
profile of strain CC-HSB- $11^{\mathrm{T}}$ is compared with those of the type strains of Muricauda species in Table 2.

For determination of the $\mathrm{G}+\mathrm{C}$ content, DNA was prepared and degraded enzymically into nucleosides as described by Mesbah et al. (1989). The nucleoside mixture was then separated by HPLC. The DNA G+C content of strain CC-HSB- $11^{\mathrm{T}}$ was $46.4 \mathrm{~mol} \%$, a value

Table 2. Comparison of cellular fatty acid compositions of strain CC-HSB $-11^{\top}$ and type strains of recognized species in the genus Muricauda

Strains: 1, M. lutaonensis sp. nov. CC-HSB- $11^{\mathrm{T}} ; 2$, M. lutimaris SMK$108^{\mathrm{T}} ; 3$, M. ruestringensis DSM $13258^{\mathrm{T}} ; 4$, M. flavescens SW- $62^{\mathrm{T}} ; 5, \mathrm{M}$. aquimarina $\mathrm{SW}-63^{\mathrm{T}}$. Data for reference type strains were taken from Yoon et al. (2008) (M. lutimaris SMK-108 ${ }^{\mathrm{T}}$ ) and Yoon et al. (2005) (remaining strains). All strains were cultivated for 3 days on MA at $30{ }^{\circ} \mathrm{C}$. Fatty acids representing less than $0.5 \%$ in all strains were omitted. ECL, Equivalent chain-length; tr, traces $(<0.5 \%)$; , not detected/not reported.

\begin{tabular}{|c|c|c|c|c|c|}
\hline Fatty acid (\%) & 1 & 2 & 3 & 4 & 5 \\
\hline \multicolumn{6}{|l|}{ Straight-chain } \\
\hline $\mathrm{C}_{15: 0}$ & - & 7.6 & 13.2 & 12.4 & 5.9 \\
\hline $\mathrm{C}_{16: 0}$ & 1.5 & $\operatorname{tr}$ & $\operatorname{tr}$ & 0.6 & $\operatorname{tr}$ \\
\hline \multicolumn{6}{|l|}{ Branched } \\
\hline iso- $\mathrm{C}_{13: 0}$ & 2.0 & - & - & - & - \\
\hline iso- $\mathrm{C}_{14: 0}$ & 2.5 & - & - & - & 0.6 \\
\hline iso- $\mathrm{C}_{15: 0}$ & 23.9 & 14.5 & 14.7 & 16.4 & 23.7 \\
\hline iso- $\mathrm{C}_{15: 1} \mathrm{G}$ & 18.2 & 21.3 & 20.5 & 19.9 & 21.6 \\
\hline anteiso- $\mathrm{C}_{15: 0}$ & 3.0 & 1.4 & 1.1 & 2.1 & 2.0 \\
\hline iso- $\mathrm{C}_{16: 0}$ & 1.4 & $\operatorname{tr}$ & - & 0.6 & 0.5 \\
\hline iso- $\mathrm{C}_{16: 1} \mathrm{G}$ & 1.1 & - & - & - & - \\
\hline iso- $\mathrm{C}_{17: 1} \omega 9 c$ & - & 1.8 & 1.4 & 1.3 & 1.5 \\
\hline \multicolumn{6}{|l|}{ Unsaturated } \\
\hline $\mathrm{C}_{15: 1} \omega 6 c$ & - & 0.6 & 0.9 & 0.9 & 0.9 \\
\hline $\mathrm{C}_{17: 1} \omega 6 c$ & - & 0.9 & 1.0 & 0.5 & 0.5 \\
\hline $\mathrm{C}_{17: 1} \omega 8 c$ & - & 0.5 & 0.7 & $\operatorname{tr}$ & - \\
\hline $\mathrm{C}_{18: 1} \omega 9 c$ & 1.0 & - & - & - & - \\
\hline \multicolumn{6}{|l|}{ Hydroxy } \\
\hline $\mathrm{C}_{15: 0} 2-\mathrm{OH}$ & 0.7 & $\operatorname{tr}$ & 0.5 & 0.6 & $\operatorname{tr}$ \\
\hline $\mathrm{C}_{15: 0} 3-\mathrm{OH}$ & - & 2.6 & 1.8 & 1.0 & 1.4 \\
\hline iso- $\mathrm{C}_{14: 0} 3-\mathrm{OH}$ & 0.5 & - & - & - & - \\
\hline iso- $\mathrm{C}_{15: 0} 3-\mathrm{OH}$ & 6.0 & 7.8 & 4.6 & 4.7 & 5.2 \\
\hline $\mathrm{C}_{16: 0} 3-\mathrm{OH}$ & 0.6 & 0.5 & $\operatorname{tr}$ & 0.8 & 0.6 \\
\hline iso- $\mathrm{C}_{16: 0} 3-\mathrm{OH}$ & 7.6 & 4.0 & 1.7 & 2.9 & 4.0 \\
\hline $\mathrm{C}_{17: 0} 2-\mathrm{OH}$ & 1.5 & 1.4 & 0.7 & 1.3 & 0.7 \\
\hline $\mathrm{C}_{17: 0} 3-\mathrm{OH}$ & $\operatorname{tr}$ & 0.8 & 1.3 & 0.7 & $\operatorname{tr}$ \\
\hline iso- $\mathrm{C}_{17: 0} 3-\mathrm{OH}$ & 18.9 & 24.6 & 20.9 & 19.9 & 17.3 \\
\hline Summed feature $3^{*}$ & 7.1 & 3.3 & 4.2 & 4.1 & 2.3 \\
\hline \multicolumn{6}{|l|}{ Unknown } \\
\hline ECL 11.543 & - & $\operatorname{tr}$ & 0.6 & - & 0.8 \\
\hline ECL 13.565 & - & 1.7 & 6.5 & 5.4 & 4.8 \\
\hline ECL 16.582 & - & 1.9 & 1.7 & 1.6 & 1.3 \\
\hline
\end{tabular}

*Summed features represent two or three fatty acids that could not be separated by the Microbial Identification System. Summed feature 3 contained iso- $\mathrm{C}_{15: 0} 2-\mathrm{OH}$ and/or $\mathrm{C}_{16: 1} \omega 7 \mathrm{c} / t$. slightly above the range reported for Muricauda species (41-45.4 mol\%).

$16 \mathrm{~S}$ rRNA gene sequence analysis showed that the closest phylogenetic neighbours of strain CC-HSB- $11^{\mathrm{T}}$ were members of the genus Muricauda in the family Flavobacteriaceae, although the level of sequence similarity was rather low. Moreover, strain CC-HSB- $11^{\mathrm{T}}$ could be differentiated from all members of the genus Muricauda by a combination of growth, morphological and physiological characteristics as well as by several differences in the fatty acid profiles.

On the basis of these results, strain CC-HSB- $11^{\mathrm{T}}$ represents a novel species in the genus Muricauda, for which the name Muricauda lutaonensis sp. nov. is proposed.

\section{Description of Muricauda lutaonensis sp. nov.}

Muricauda lutaonensis (lu.tao.nen'sis. N.L. fem. adj. lutaonensis pertaining to Lutao, the geographical origin of the type strain).

Cells are Gram-staining-negative, strictly aerobic, nonspore-forming rods, displaying appendages and vesicles. Cells are $0.3-0.5 \mu \mathrm{m}$ wide and $8.0-15.0 \mu \mathrm{m}$ long. Devoid of flagellar and gliding motility. Growth is visible after $24 \mathrm{~h}$ of incubation on MA at $37^{\circ} \mathrm{C}$. Colonies on MA are shiny, translucent, golden yellow and circular with regular, nonspreading edges. Growth does not occur on tryptic soy, nutrient or yeast extract agars. Growth occurs at $25-55{ }^{\circ} \mathrm{C}$ (optimum $37-45{ }^{\circ} \mathrm{C}$ ), but not at 20 or $60{ }^{\circ} \mathrm{C}$. Growth occurs at $\mathrm{pH}$ 6-9 (optimum $\mathrm{pH} 8$ ) and in the presence of 2-6\% $\mathrm{NaCl}$ (optimum 3-5\%) in MB. Growth does not occur in tryptic soy broth or on R2A agar without supplementation with sea salts or seawater. Growth does not occur on R2A and tryptic soy agars supplemented with $\mathrm{NaCl}$ only. Natural seawater or artificial sea salts (1-3\%) are required. No anaerobic growth on MA supplemented with potassium nitrate. Nitrate is not reduced to nitrite. Flexirubin-type pigments are not produced and poly- $\beta$ hydroxybutyrate granules are not accumulated. Oxidaseand catalase-positive. Acid is not produced from D-glucose, D-xylose, L-arabinose, D-galactose, D-sorbitol, myo-inositol, D-ribose, D-mannitol or L-rhamnose. The following carbon sources are utilized in the Biolog GN II system: dextrin, cellobiose, D-fructose, gentiobiose, $\alpha$-D-glucose, $\alpha$-lactose, lactulose, maltose, D-mannose, melibiose, raffinose, sucrose, trehalose, turanose, pyruvic acid methyl ester, acetic acid, $\alpha$-ketobutyric acid, succinic acid, L-glutamic acid, L-proline, L-threonine, inosine and $\alpha$-D-glucose 1-phosphate. All other carbon sources in the GN II system are not utilized. Positive reactions (API 20E and 20NE) for the production of acetoin, hydrolysis of aesculin, $\beta$-glucosidase and $\beta$-galactosidase activities and assimilation of mannose. Sensitive to $\left(1^{-1}\right)$ ampicillin/sulbactam $(8 / 4-16 / 8 \mathrm{mg})$, ticarcillin $(16 \mathrm{mg})$, ticarcillin/clavulonic acid $(16 / 2 \mathrm{mg})$, piperacillin $(16 \mathrm{mg})$, piperacillin/tazobactam $(64 / 4 \mathrm{mg})$, ceftazidime $(8-16 \mathrm{mg})$, cefepime $(8-16 \mathrm{mg})$, imipenem $(4-8 \mathrm{mg})$, meropenem $(4-8 \mathrm{mg})$ and ciprofloxacin (1-2 mg); resistant to $\left(\mathrm{l}^{-1}\right)$ amikacin $(16-32 \mathrm{mg})$, genta- 
micin (4-8 $\mathrm{mg})$, tobramycin $(4-8 \mathrm{mg})$, cotrimoxazole $(2-$ $38 \mathrm{mg}$ ) and colistin (2 mg) (ATB PSE 5). Additional phenotypic features are given in Table 1 . The fatty acid profile is characterized by large amounts of branched chain and hydroxy fatty acids (Table 2). The predominant polar lipids are diphosphatidylglycerol, phosphatidylglycerol, phosphatidylethanolamine, three unidentified phospholipids and three unidentified glycolipids. The major respiratory lipoquinone is MK-6. The DNA G + C content of the type strain is $46.4 \pm 1 \mathrm{~mol} \%$.

The type strain is CC-HSB- $11^{\mathrm{T}}\left(=\mathrm{BCRC} 17850^{\mathrm{T}}=\mathrm{KCTC}\right.$ $22339^{\mathrm{T}}$ ), isolated from water of a coastal hot spring located on Lutao, a small volcanic island in the Pacific Ocean off the eastern coast of Taiwan.

\section{Acknowledgements}

This research work was kindly supported by a grant from the National Science Council, Taiwan, and the Council of Agriculture, EY, Taiwan. We thank W. S. Huang and S. Y. Lin for technical assistance.

\section{References}

Bernardet, J.-F., Nakagawa, Y. \& Holmes, B. (2002). Proposed minimal standards for describing new taxa of the family Flavobacteriaceae and emended description of the family. Int J Syst Evol Microbiol 52, 1049-1070.

Bruns, A., Rohde, M. \& Berthe-Corti, L. (2001). Muricauda ruestringensis gen. nov., sp. nov., a facultatively anaerobic, appendaged bacterium from German North Sea intertidal sediment. Int $J$ Syst Evol Microbiol 51, 1997-2006.

Chung, Y. C., Kobayashi, T., Kanai, H., Akiba, T. \& Kudo, T. (1995). Purification and properties of extracellular amylase from the hyperthermophilic archeon Thermococccus profundus DT5432. Appl Environ Microbiol 61, 1502-1506.

Collins, M. D. \& Jones, D. (1980). Lipids in the classification and identification of coryneform bacteria containing peptidoglycans based on 2,4-diaminobutyric acid. J Appl Bacteriol 48, 459-470.

Cowan, S. T. \& Steel, K. J. (1965). Manual for the Identification of Medical Bacteria. London: Cambridge University Press.

Embley, T. M. \& Wait, R. (1994). Structural lipids of eubacteria. In Chemical Methods in Prokaryotic Systematics, pp. 121-161. Edited by M. Goodfellow \& A. G. O’Donnell. Chichester: Wiley.

Gerhardt, P., Murray, R. G. E., Wood, W. A. \& Krieg, N. R. (editors) (1994). Methods for General and Molecular Bacteriology. Washington, DC: American Society for Microbiology.

Kämpfer, P. \& Kroppenstedt, R. M. (1996). Numerical analysis of fatty acid patterns of coryneform bacteria and related taxa. Can J Microbiol 42, 989-1005.
Kluge, A. G. \& Farris, J. S. (1969). Quantitative phyletics and the evolution of anurans. Syst Zool 18, 1-32.

Kumar, S., Tamura, K., Jakobsen, I. B. \& Nei, M. (2001). MEGA2: molecular evolutionary genetics analysis software. Bioinformatics $\mathbf{1 7}$, $1244-1245$.

Lányí, B. (1987). Classical and rapid identification methods for medically important bacteria. Methods Microbiol 19, 1-67.

Lee, S. D. (2007). Tamlana crocina gen nov., sp. nov., a marine bacterium of the family Flavobacteriaceae, isolated from beach sediment in Korea. Int J Syst Evol Microbiol 57, 764-769.

Leifson, E. (1963). Determination of carbohydrate metabolism of marine bacteria. J Bacteriol 85, 1183-1184.

Mesbah, M., Premachandran, U. \& Whitman, W. B. (1989). Precise measurement of the $\mathrm{G}+\mathrm{C}$ content of deoxyribonucleic acid by highperformance liquid chromatography. Int J Syst Bacteriol 39, 159-167.

Miller, P. H., Wiggs, L. S. \& Miller, J. M. (1995). Evaluation of AnaeroGen system for growth of anaerobic bacteria. J Clin Microbiol 33, 2388-2391.

Minnikin, D. E., O’Donnell, A. G., Goodfellow, M., Alderson, G., Athalye, M., Schaal, K. \& Parlett, J. H. (1984). An integrated procedure for the extraction of bacterial isoprenoid quinones and polar lipids. J Microbiol Methods 2, 233-241.

Reichenbach, H. (1992). The order Cytophagales. In The Prokaryotes, 2nd edn, vol. 4, pp. 3631-3675. Edited by A. Balows, H. G. Trüper, M. Dworkin, W. Harder \& K. H. Schleifer. New York: Springer.

Saitou, N. \& Nei, M. (1987). The neighbor-joining method: a new method for reconstructing phylogenetic trees. Mol Biol Evol 4, 406-425.

Sasser, M. (1990). Identification of bacteria by gas chromatography of cellular fatty acids. USFCC Newsl 20, 16.

Stackebrandt, E. \& Goebel, B. M. (1994). Taxonomic note: a place for DNA-DNA reassociation and $16 \mathrm{~S}$ rRNA sequence analysis in the present species definition in bacteriology. Int J Syst Bacteriol 44, 846-849.

Thompson, J. D., Gibson, T. J., Plewniak, F., Jeanmougin, F. \& Higgins, D. G. (1997). The CLUSTAL_X windows interface: flexible strategies for multiple sequence alignment aided by quality analysis tools. Nucleic Acids Res 25, 4876-4882.

Yoon, J.-H., Lee, M.-H., Oh, T.-K. \& Park, Y.-H. (2005). Muricauda flavescens sp. nov. and Muricauda aquimarina sp. nov., isolated from a salt lake near Hwajinpo Beach of the East Sea in Korea, and emended description of the genus Muricauda. Int J Syst Evol Microbiol 55, 1015-1019.

Yoon, J.-H., Kang, S.-J., Jung, Y.-T. \& Oh, T.-K. (2008). Muricauda lutimaris sp. nov., isolated from a tidal flat of the Yellow Sea. Int J Syst Evol Microbiol 58, 1603-1607.

Young, C.-C., Kämpfer, P., Shen, F.-T., Lai, W.-A. \& Arun, A. B. (2005). Chryseobacterium formosense sp. nov., isolated from the rhizosphere of Lactuca sativa L. (garden lettuce). Int J Syst Evol Microbiol 55, 423-426. 